\title{
The regional MNE and coordination of MNE organizational structures
}

Book or Report Section

Accepted Version

Nguyen, Q. T. K. (2018) The regional MNE and coordination of MNE organizational structures. In: Cook, G., Johns, J., McDonald, F., Beaverstock, J. and Pandit, N. (eds.) The Routledge Companion to the Geography of International Business. Routledge Companions in Business, Management and Accounting. Routledge. ISBN 9781138953345 Available at http://centaur.reading.ac.uk/69646/

It is advisable to refer to the publisher's version if you intend to cite from the work. See Guidance on citing.

Publisher: Routledge

All outputs in CentAUR are protected by Intellectual Property Rights law, including copyright law. Copyright and IPR is retained by the creators or other copyright holders. Terms and conditions for use of this material are defined in the End User Agreement. 


\section{www.reading.ac.uk/centaur}

\section{CentAUR}

Central Archive at the University of Reading

Reading's research outputs online 


\title{
THE REGIONAL MNE AND COORDINATION OF MNE ORGANIZATIONAL STRUCTURES
}

\author{
Quyen T.K. Nguyen (Ph.D.) (Corresponding author) \\ Lecturer in International Business and Strategy \\ Henley Business School \\ International Business and Strategy \\ University of Reading \\ Whiteknights Campus, Reading, England RG6 6AH \\ E-mail: t.k.q.nguyen@henley.ac.uk
}




\section{THE REGIONAL MNE AND COORDINATION OF MNE ORGANIZATIONAL STRUCTURES}

\section{INTRODUCTION}

This chapter provides an overview of the key insights resulting from international business (IB) research on the regional strategy of multinational enterprises (MNEs) and coordination of MNEs' organization structures. It consists of three main sections. The first section describes the debate of globalization and regionalization at the firm level with a focus on the actual behavior of MNEs. It discusses the complex nature of regional strategy of MNEs, the definitions and measurements of regions, and the effects of regional strategy on the international expansion and performance of MNEs. The second section discusses the theory of regional MNE, which explains why MNEs concentrate their business activities within their home region. The liability of intra-regional expansion is lower than the liability of interregional expansion and there is unnoticed location-boundedness and region-boundedness of firm-specific advantages (FSAs). The third section discusses the regional organizational and management structures. The chapter concludes on the regional strategy and structure of MNEs.

\section{THE DEBATE OF REGIONALIZATION VERSUS GLOBALIZATION}

\section{Empirical evidence on the regional nature of MNEs and their foreign subsidiaries}

Since 2000s, the concept of globalization attracts attention of academics and managers alike. A number of scholars (Levitt, 1983; Prahalad and Doz, 1987; Bartlett and Ghoshal, 1989; Yip, 1992; Govindarajan and Gupta, 2001) presume the growth of globalization of markets, and advocate total global strategy. In 1992, George Yip published a book "Total Global Strategy: Managing for Worldwide Competitive Advantage". Govindarajan and Gupta published a book in 2001 "The Quest for Global Dominance". A few years later in 2005, Thomas Friedman 
published a popular book "The World is Flat: A History of the Twenty-First Century". Such global strategy aims to yield economies of scale, a so-called integration strategy.

In contrast, Rugman (2000) challenges the globalization myth and presents regionalization theory in his thought-provoking book "The End of Globalization: Why Global Strategy is a Myth and How to Profit from the Realities of Regional Markets". Rugman and Collinson (2012, p.7) argue that "in its extreme form, globalization means the existence of a perfectly integrated world economic system. In such a global system, there would be perfect mobility of financial capital, goods and people. There would be a global commonality whereby identical values and tastes would occur. Yet, such a situation of perfect integration and globalization does not exist”. Rugman (2000) shows regionalization patterns of trade, foreign direct investment (FDI) flows, and regional strategy of individual MNEs through detailed analysis using case studies. Rugman (2000) provides analytical theoretical frameworks to explain this regionalization phenomenon. Rugman and Verbeke (2004) and Rugman (2005) further rebut the presumption of globalization of business by showing that the majority of the world's largest firms of the Fortune Global 500 are not global, but regional. Rugman (2005) demonstrates that MNEs pursues regional rather than global strategies and that the regions are triad based of North America, Europe and Asia Pacific. A firm which pursues a global strategy operates across these three broad triad regions of the world with equal distribution of sales and assets. However, Rugman and Verbeke (2004) find that there are only nine global firms.

Ten years after the publication of Rugman and Verbeke (2004), Oh and Rugman (2014) present a 10-year longitudinal data and find that MNEs have a strong home-region concentration in their sales and assets. Specifically, these firms generate 70 percent of their total sales and have 72 percent of their total assets within the home region of the broad triad. The data of assets reflect investments in production, and/or distribution, and/or R\&D of MNEs. 
The literature has generated rich and abundant empirical evidence of the regional nature of MNEs. These include MNEs in the Fortune Global 500 (Rugman, 2000, 2005, 2009; Rugman and Hodgetts, 2001; Rugman and Verbeke, 2004; Rugman and Oh, 2013; Oh and Rugman, 2014); European MNEs (Rugman and Collinson, 2005; Oh, 2009; Rugman and Oh, 2010); Japanese MNEs (Delios and Beamish, 2005; Collinson and Rugman, 2008); Asian MNEs (Collinson and Rugman, 2007; Rugman and Oh, 2008a); Korean MNEs (Rugman and Oh, 2008b); ASEAN MNEs (Sukpanich and Rugman, 2010); Chinese MNEs (Yin and Choi, 2005; Rugman and Li, 2007; Rugman, Nguyen \& Wei, 2016) and emerging market MNEs (Rugman and Nguyen, 2014).

The regionalization patterns are empirically confirmed with evidence of MNEs operating in different industries. These include firms in automobile industry (Rugman and Collinson, 2004); retail industry (Rugman and Girod, 2003; Mohr, Fastoso, Wang and Shirodkar, 2014; Oh, Sohl and Rugman, 2015); pharmaceutical industry (Rugman and Brain, 2004); banking and financial services (Grosse, 2005); cosmetics industry (Oh and Rugman, 2006, 2007); food and beverage industry (Filippaios and Rama, 2008); merchandising industry (Rugman and Sukpanich, 2007); and service industry (Rugman, 2003a; Li, 2005; Rugman and Verbeke, 2008b).

In a related manner, Nguyen (2014), and Nguyen and Rugman (2015) find that the foreign subsidiaries of MNEs operate regionally, not globally. These scholars conduct a survey with British multinational subsidiaries in six South East Asian countries and report that these subsidiaries generate 95 percent of their total sales in the broad Asia Pacific region (home region). Similarly, Nguyen (2015) uses an original dataset of publicly-listed multinational subsidiaries in five South East Asia countries, with parent firms headquartered in the United States, the United Kingdom, France, Germany, the Netherlands, Switzerland, Japan, Hong Kong, Malaysia, Indonesia, the Philippines, Singapore, Thailand, China, India, Taiwan, South 
Africa, and Brazil. Nguyen (2015) finds that these subsidiaries generate 92 percent of their total sales in the Asia Pacific region (home region).

In summary, the research on regionalization has made significant development with more theoretical and empirical contributions (for a comprehensive literature review, see Oh, 2009; Kolk, 2010; Banalieva \& Dhanaraj, 2013; Nguyen, 2014; for a recent debate, see Verbeke \& Asmussen, 2016; Mudambi \& Puck, 2016). A large volume of literature shows that most MNEs and their foreign subsidiaries from various countries and industries pursue a home-regional strategy. There are very few firms (only nine firms) which pursue a global strategy (Rugman and Verbeke, 2004). There is a lack of evidence towards globalization of MNEs.

\section{Definition of regions}

The major debates in this literature are how to define and how to measure a region (Aharoni, 2006; Aguilera, Flores \& Vaaler, 2008; Asmussen, Pedersen, and Petersen, 2007; Asmussen, 2009; Dunning, Fujita \& Yakova, 2007; Osegowitsch \& Sammartino, 2008; Seno-Alday, 2009; Stevens \& Bird, 2004; Westney, 2006; Wolf, Dunemann and Egelhoff, 2012; Verbeke \& Kano, 2012; Banalieva \& Dhanaraj, 2013; Flores, Aguilera, Mahdian \& Vaaler, 2013). Rugman and his co-authors' original conceptualization of the triad region follows Ohmae's (1985) grouping of the core triad of North America, Western Europe and Japan. With the increasing of regional economic integration, the core triad has been extended to the broad triad of North America, Europe and Asia Pacific (Rugman, 2000; Rugman \& Collinson, 2012). Rugman \& Verbeke (2008a) maintain that the triad is relevant because it is the home of most large MNEs in the world, as well as the locus for the bulk of radical innovation in most industries.

Arregle, Beamish and Herbet (2009) use geographic criteria to define regions. Dunning et al. (2007) define regions by culture clusters. They confirm the broad regional patterns using macro FDI data. Aguilera et al. (2007) and Flores et al. (2013) suggest different definitions of regions, such as economic development, trade, investment flows and income; socio-cultural and 
language; political, institutional proximity, including religion, political openness, and institutional systems; and the 25 United Nations of geographic classification. Ronen and Shenkar (2013) suggest 11 global/ regional cultural clusters from their study of 96 countries. It is important to highlight that Rugman and his co-authors use manually collected and carefully hand coded data from firms' annual reports in their empirical works on the regionalization of MNEs. However, they are often questioned by other scholars on the use of the broad triad regions instead of other conventions. Rugman (2003b, 2005) argues that the triad regions are the appropriate regions for the simple reality that the MNEs publicly report the broad geographic regions of their sales, assets, profits, and employees in accordance with accounting standards.

Nguyen (2014) contributes to the regionalization debate by offering explanation how firms define regions in compliance with international accounting standards. Specifically, the $U S$ GAAP FASB 131 Disclosures about Segments of an Enterprise and Related Information (issued in 1997 and effective for fiscal years beginning after December 15, 1997), and IFRS8Operating Segments (issued in 2006 and applies to annual periods beginning on or after 1 January 2009) provide guidance on segment reporting and disclosures. Publicly listed entities are required to disclose information about operating geographic segments, business segments (products and services) and their major customers (see IFRS8, IAS Plus website, 2015).

Segment information is based on internal management reports, both in the identification of operating segments and measurement of disclosed segment information. Reportable segments are operating segments or aggregation of operating segments that meet specified criteria of either revenues, or profit/loss, or assets at 10 percent or more of the combined revenues, or profit/loss or assets (for detailed information, see IFRS8, IAS Plus website, 2015). In practice, firms classify broad geographic regions on the basis of organizational structures and management reporting (Nguyen, 2014). 
It would be highly impractical for firms to use $25 \mathrm{UN}$ geographic regions or 11 global cultural clusters or other criteria (as suggested by IB scholars) in their financial reporting and disclosures. Such an approach does not comply with accounting regulations, because data of certain geographic regions or cultural clusters are likely below the threshold of 10 percent for disclosures. Furthermore, the costs of reporting and disclosures will exceed the benefits whereas the accounting rules emphasize the opposite.

Firms are not required to report geographic segments of sourcing and purchasing. However, a number of IB scholars use a global value chain perspective to argue for the globalization of MNE activities. In reality, firms may voluntarily disclose information of sourcing. For example, IKEA, a large privately-owned furniture retailer founded in Sweden in 1943, published for the first time in 2010 some information about its financial data. It is clear that IKEA is a home region based MNE in terms of purchases, sales, and employees. For the year 2010, IKEA purchased 62 percent of goods from Europe, 34 percent from Asia and 4 percent from North America. IKEA generated 79 percent of its total sales in Europe, 15 percent from North America, and 6 percent from Asia and Australia. IKEA had 103,500 employees in Europe, 15,500 employees in North America, and 8,000 employees in Asia and Australia (IKEA, Welcome Inside, 2010).

\section{Measures of regionalization}

Rugman (2000; 2005) and Rugman \& Verbeke (2004) use the ratio of home-region sales divided by total sales as a measure of firms' degree of regionalization, in which home-region sales are defined as the home country domestic sales plus rest of home region sales. Foreign sales over total sales are sales in rest of home region plus sales in rest of world.

In the early period of implementing operating segment accounting standards, firms tend to report geographic segments of sales (the data which Rugman and Verbeke, 2004 and Rugman, 2005 use in their studies). However, Rugman and Verbeke (2004) and Rugman (2005) are 
criticized for using only sales data (Aharoni, 2006). Subsequently, firms have disclosed more information on geographic segments of sales, assets and employees. Oh and Rugman (2014) present a 10-year longitudinal data of sales and assets of the world's largest firms in Fortune Global 500, in which the regionalization trend remains unchanged.

Rugman \& Verbeke (2004) provide thresholds to classify firms into different categories, namely, home-regional, bi-regional, host-regional, and global firms. Home-region oriented firms have at least $50 \%$ of their sales in their home region of the triad. Bi-regional firms have over $20 \%$ of their sales in at least two regions of the triad and less than $50 \%$ of their sales in their home region. Host-region oriented firms have over $50 \%$ of their sales in a foreign region of the triad. Global firms mean firms that have at least $20 \%$ of their sales in each of the three regions of the triad, but not more than $50 \%$ in any one region. The same categories have been applied to assets in follow-up studies by Rugman and co-authors.

However, Osegowitsch \& Sammartino (2008) challenge the regionalization measure in Rugman and Verbeke (2004), and criticize the thresholds as arbitrary because the thresholds can be manipulated by normalizing data. They also suggest that the regionalization pattern should be tested using longitudinal data. Similarly, Stevens \& Bird (2004) question the specification of the threshold value and the categories. Other studies (Delios \& Beamish, 2005; $\mathrm{Li}, 2005)$ argue that including home country domestic sales in measuring regionalization overstates the degree of regionalization (Banalieva \& Dhanaraj, 2013).

A number of scholars have developed two alternative measures of regionalization. The first measure is the ratio of rest of home region sales to foreign sales, in which home-country domestic sales are excluded from home region sales (Banalieva \& Eddleston, 2011; Delios \& Beamish, 2005; Li, 2005; Rugman \& Verbebe 2008a). They argue that the IB literature should focus on foreign sales only and disregard home country domestic sales. However, this suggestion is problematic as domestic sales are highly important for firms from large 
economies, such as the United States, China, etc. The second measure is the ratio of rest of home region sales to total sales (Elango, 2004; Rugman \& Verbeke, 2008a). Asmussen (2009) suggests an alternative measure normalizing the ratios using GDP data; however, Banalieva \& Dhanaraj (2013) argue that Asmussen's regionalization measure has little practical appeal.

The debate on the definition and measures of regionalization reveals that IB scholars have not taken into account developments in international accounting standards (IFRS8 and US GAAP FAS 131) which firms have to comply. The IB literature generally tends to use data from large databases but pays no attention to underlying accounting principles. Indeed, geographic regions are defined and measured by firms (Nguyen, 2014; Rugman, 2005a). Rugman and his coauthors use regional data as disclosed in firms' annual reports (see Rugman's responses (2005a) to comments by Stevens and Bird, 2004). This reflects Rugman's distinctive research methodology (Casson, 2016), and his philosophy in theory development which must be firmly grounded in data and empirical evidence of business reality and managerial insights.

\section{Regionalization and international expansion}

A number of studies have examined the relationship between regional strategy and entry modes (Arregle et al., 2009; Arregle, Miller, Hitt \& Beamish, 2013; Oh \& Rugman, 2007), international expansion (Rugman \& Oh, 2013), international competitiveness (Rugman, Oh and Lim, 2012), and human resource management (Edwards, Jalette, and Tregaskis, 2012). For example, Rugman and Oh (2013) use variance component to analyze the effects of home region, country, firm, and year on international expansion of firms. They find that the home region effect outperforms the country effect. Together, the regional and industry effects explain most of the geographic expansion of MNEs, whereas country, firm, and year effects are very minor. The findings suggest the importance of large regions of the triad as the relevant unit of analysis for business strategy to supplement the conventional focus on the country. 
The global versus regional strategy also attracts debate in the fields of marketing and strategic management. A number of studies find that firms focus on regional strategy due to differences in consumers' tastes and preferences, barriers to the implementation of global strategy and complexity of global operations (Morrison, Ricks, and Roth, 1991; Roth and Morrison, 1992). Lewitt (1983) argues that MNEs should not worry much about customizing products and services to cultural preferences. Technology has largely homogenized consumer preferences, in which most consumers simply want quality, reliability and low price. Therefore, MNEs should standardize their products and services worldwide in order to achieve economies of scale, and should implement global strategies across all markets.

Yet, Douglas and Wind (1987) critically examine the key assumptions underlying Lewitt's global philosophy and the conditions under which it is likely to be effective. They highlight the barriers to its implementation. They conclude that global standardization is just one of many strategies in international markets. In reality, it is very challenging to sell the same products and services across borders as advocated by Levitt (1983). It has now widely recognized the benefits of integration resulting from global scale economies can only be reaped if accompanied by strategies of national responsiveness by both external pressures for local adaptation and internal pressures for requisite variation (Ghobadian, Rugman and Tung, 2014). The concepts of global integration and national responsiveness have been developed by Bartlett and Ghoshal (1989) and Prahalad and Doz (1987). Global integration can be defined as the production and distribution of products and services of a homogenous type and quality on a worldwide basis. To a large extent, MNEs have homogenized tastes and helped to spread international consumerism (Rugman and Collinson, 2012) as MNEs are the drivers of globalization. For example, there has been a growing acceptance of standardized consumer electronic goods, and similar products. However, the goal of efficient economic performance through a universal globalization strategy has left MNEs open the charge that they are 
overlooking the need to address national concerns (Rugman and Collinson, 2012). National responsiveness is the ability of MNEs to understand different consumer tastes in segmented regional markets and to respond to the different national standards and regulations imposed autonomous governments and agencies. Multinationals will continually have to deal with the twin goals of economic integration and national responsiveness (Rugman and Collinson, 2012). Nguyen (2014) finds that there is no evidence of the dominance of global products in the product and service offering portfolios of British multinational subsidiaries in manufacturing and services sectors. For manufacturing subsidiaries, regional product offerings account for 38 percent, local for 16 percent, and global for 46 percent. Service subsidiaries focus more on local and regional service offerings, of which regional service offerings account for 24 percent, local for 41 percent, and global for 35 percent.

\section{Regionalization and performance of the firm}

Rugman $(2000,2005)$ and Rugman \& Verbeke (2004) focus on the regional strategy of the MNE. Subsequent studies examine the implications of such regionalization strategy on performance of the parent-level MNE. However, the results are mixed. Studies by Qian, Khoury, Peng, and Qian (2010), Rugman, Kudina, and Yip, (2007), Rugman \& Sukpanich (2007) find a positive effect of regionalization on performance. On the contrary, studies by Delios \& Beamish (2005) and Elango (2004) find a negative effect. Banalieva \& Eddleston (2011), Li (2005), and Banalieva \& Dhanaraj (2013) have adopted contingency perspectives to examine the simultaneous effects between home region strategy and performance in an attempt to get a better understanding of the direction of causality between performance and home region strategy. They find that performance significantly reduces home region orientation, but home-region orientation does not have a significant effect on performance.

Gilbert and Heinecke (2014) argue that the relationship between regional strategies and MNE performance might be contingent upon conditions and developments within the firm and 
external environments (Banalieva and Dhanaraj, 2013; Bausch, Fritz, and Boesecke, 2007; Heinecke, 2011). Gilbert and Heinecke (2014) examine success factors of regional strategies for MNEs by exploring the degree of regional management and product/ service adaptations to regional market requirements and regional differences, which might lead to better regional performance. They find that low degrees of regional management autonomy and high levels of regional product/ service adaptation are appropriate for MNEs to be regionally successful. The possible adverse effects of high degrees of regional management autonomy on regional success are mitigated by an MNE's inter-regional distance. The regional performance with high levels of regional product/service adaptation is positively influenced by both an MNE's regional orientation and its inter-regional distance. Their findings imply that MNEs should optimize the regional success by varying the regional management autonomy and regional product/service adaptation in light of the organizational and environmental context.

Nguyen (2015) examines the determinants of home region strategy of the multinational subsidiary and the impact of such a strategy on its performance. Nguyen (2015) draws upon new internalization theory to develop a theory-driven model and empirically test the simultaneous relationships between home region strategy and performance of the subsidiary. The findings are that subsidiary-level downstream knowledge (marketing advantages), and the geographic location of the subsidiary in the same home region as of the parent firm are key antecedents of a subsidiary's home-region strategy. A subsidiary's profitability reduces home region orientation; however, home region strategy has an insignificant effect on performance. This study advances the existing literature on the regional nature of parent-level multinational enterprises (MNEs) by demonstrating that their quasi-autonomous subsidiaries also operate mainly on a home-region basis.

\section{THEORY OF REGIONAL MULTINATIONALS}


Rugman and Verbeke (2004) and Rugman (2005), Rugman and Verbeke (2008a) develop the theory of regional MNEs, in which their business activities are limited in home region. Rugman and Verbeke $(2003,2005)$ focus on regional strategy as the substantive core of a strategic firmlevel decision ( $\mathrm{Oh}$ and $\mathrm{Li}, 2015)$. The regional strategy is a more refined alternative to a transnational solution which is built upon the concept of global integration and national responsiveness (Bartlett and Ghoshal, 1989; Prahalad and Doz, 1987).

Rugman and Verbeke (1992) develop the concepts of non-location bound firm-specific advantages (NLB) and location-bound (LB) firm-specific advantages (FSAs), which they refer to as new internalization theory. Rugman and Verbeke (1992) argue that the benefits of integration, in the form of economies of sales and economies of scope and benefits of exploiting national differences require NLB FSAs, i.e. strengths specific to the firm attributable to R\&D knowledge, patented technology, and global brands which are internationally transferrable with low cost and without adaptation. This transfer can take place in the form of intermediate or final outputs. In contrast, the benefits of national responsiveness require LB FSA, which are tied to a particular location, country, or a set of countries or a region, for example, the development of new knowledge and the access to complementary resources in the host countries by the foreign subsidiary. The LB FSAs and NLB FSAs can be generated by both parent firms and foreign subsidiaries and diffused in the home operation, host operation and MNE networks (Rugman and Verbeke, 1992; 2001).

According to Rugman (2005), the transnational solution requires a firm to effectively access and to deploy the required dual knowledge bundles of NLB and LB FSAs. Each generic subsidiary type (strategic leaders, contributors, implementers and black holes) has access to a set of FSAs bundles and resources.

The majority of MNEs operate on a home region basis of the broad triad. Thus, there is a need to develop region-bound RB FSAs (Rugman, 2005; Collinson and Rugman, 2008). Rugman 
and Sukpanich (2006) find that FSAs are region-bounded, i.e. they can be deployed across national borders, but only in a limited geographic region due to the tacit nature of knowledge and unnoticed location-boundedness (Nguyen, 2015).

Furthermore, Rugman (2005) maintains that the required set of FSAs in upstream (back-end) activities to achieve broad geographic sourcing $(R \& D$, raw materials and intermediate inputs, labour and capital) and production may be very different from the FSAs required for downstream activities (customer-end) in the interface with customers (marketing, sales and distribution). In this case, a new set of FSAs developed by foreign subsidiaries, which are known as subsidiary-specific advantages (SSAs) (Rugman and Verbeke, 2001; Rugman, 2014). They are important to facilitate the access to customers in local and regional markets (for a comprehensive discussion on FSAs, see Rugman, Verbeke and Nguyen, 2011). Nguyen (2015) shows that SSAs in marketing created by foreign subsidiaries in the South East Asian region are more transferrable within the broad home region of the Asia Pacific than across regions.

According to Rugman and Verbeke (2004, 2007) and Rugman (2005), an important explanation of the significant differences in geographic international expansion costs is that the liability of intra-regional expansion (i.e. expansion within a home region) is lower than the liability of inter-regional expansion (i.e. expansion across regions). In addition, Qian, Li, and Rugman (2013) emphasize that the concepts of "the liability of country foreignness (LCF)" and "the liability of regional foreignness (LRF)" are different. Qian et al. (2013) argue that the costs of the LCF are directly associated with spatial distance, and the structural, relational and institutional costs (Zaheer, 2002; Bell, Filatotchev and Rasheed, 2012). The LRF is the cost of doing business across different regions due to increasing complexities in internal coordination, the bounded rationality and bounded reliability problems (Verbeke, 2013; Verbeke and 
Greidanus, 2009), and differences in external environments across regions (for a detailed discussion, see Qian et al., 2013).

Rugman and Verbeke (2008a) demonstrate that intra-regional distance in the EU, North America and Asia Pacific is decreasing thanks to regional economic integration, which results in a reduction of trade and investment barriers and more institutional convergence. Firms can take advantage of free trade agreements and regional integration schemes, e.g. The North America Free Trade Agreement (NAFTA), The European Union (EU), The Association of South East Asian Nations (ASEAN) Free Trade Agreement (AFT), ASEAN free trade agreements with Japan, Korea, India, China, Australia and New Zealand (ASEAN+6). Thus, expansion within the home region will often continue to be easier than equivalent growth elsewhere in the world, especially sales and profitability.

\section{REGIONAL ORGANIZATIONAL AND MANAGEMENT STRUCTURES}

Regional management structures represent an efficient intra-firm governance mechanism to support the regional strategy of MNEs (Rugman and Verbeke, 2008c). Rugman and Collinson (2005) argue that regional management structures are established to meet the needs of regional customers. Regional-level managerial support may include regional cash management (Venzin, Kumar and Kleine, 2008), the coordination of regional production (Rugman and Collinson, 2004), and regional product development (Verbeke and Asmussen, 2016). Rugman (2005) observes that a HQ-based and centralized decision-making approach might lead to a lack of success in foreign markets because it may not always appropriate to address regionspecific challenges which may be better handled through region-based organizational structures.

Furthermore, regional management structures overcome the problems of bounded rationality and bounded reliability of managers at corporate headquarters (HQs) in managing a diverse network of foreign subsidiaries (Rugman and Verbeke, 2005; Verbeke \& Kenworthy, 2008). 
According to Verbeke (2013), bounded rationality reflects the limitations of an intended rational human behavior to absorb, process, and act upon complex and often insufficient information. Bounded rationality affects managers in the deployment and exploitation of FSAs (Verbeke and Kenworthy, 2008). Consequently, HQs delegate decision making to the regional headquarters (RHQs) (Rugman, 2005) as the latter has better access to information of national and regional markets. Bounded rationality creates the need for regional management structures when MNEs establish locally-oriented subsidiaries in distant regions and when the number of different economies within a particular region increases (Enright, 2005a; Gilbert and Heinecke, 2014).

On the other hand, bounded reliability describes the limitations of individuals regarding their realization of a promised outcome (Verbeke and Kenworthy, 2008; Verbeke and Greidanus, 2009; Verbeke, 2013). Bounded reliability of foreign subsidiaries is influenced by the distance to corporate HQs, including immediate sanctions and reward systems, monitoring and controlling mechanisms (Verbeke and Kenworthy, 2008; Verbeke and Greidanus, 2009; Verbeke, 2013). Bounded reliability explains how regional management structures might be influenced by the geographic proximity to HQs (Yeung, Poon and Perry, 2001).

Bartlett and Ghoshal (1989) advocate the adoption of the transnational solution, especially for MNEs with widely dispersed assets and sales. Bartlett and Ghoshal (1989) argue that in order to evolve toward the transnational solution, managers should pursue an incremental, path dependent trajectory of change. The selectivity requires to manage the transformation towards a transnational company in three facets, namely, administrative heritage, extensive socialization and the roles assigned to national subsidiaries, given the attractiveness of their location and their contribution to new NLB knowledge development (for detailed discussion, see Rugman and Verbeke, 2008c). 
Rugman and Verbeke (2008c) make two important points. First, they argue that most large MNEs have not been successful in replicating the market performance achieved at home in other markets, especially distant host regions, which often require a completely different FSACSA configuration than the one that proves successful in the home market. Second, introducing a regional component in strategy and structure may address the managerial challenges expected for firms with a vastly different asset base and market position in various regions of the world. Rugman (2005) argues that the strategic importance of each triad region, combined with the differences in market characteristics faced by MNEs in each of these regions suggest the importance of geographic components in the MNEs' structure.

Indeed, there is a large body of literature on the need for a fit between strategy and structure in MNEs as a precondition for survival, profitability, and growth. Studies on the strategy and structure of MNEs can be attributed to Egelhoff (1982, 1988a) and Wolf and Egelhoff (2002). Egelhoff $(1988 b, 1991)$ uses an information processing theory to study the strategy-structure fit. Egelhoff (1982, p 441) views the use of geographic divisions in MNEs as appropriate in cases whereby, "operations within a region are relatively large, complex and sufficiently different from other regions that opportunities for specialization and economies of scale are greater within a region than they are along worldwide product lines".

His empirical work shows that three variables which are critical to choose geographic divisions include size of foreign operations measured by percentage of a firm's sales occurring outside of the parent country (the ratio of foreign sales over total sales F/T), size of foreign manufacturing measured by the percentage of foreign sales accounted for by foreign manufacturing rather than exports from the parent country, number of foreign subsidiaries measured by the number of foreign countries in which the company had either resident marketing or manufacturing operations. He identifies an area division structure which MNEs can use to divide the world into geographic areas, each with its own HQs, responsible for all 
products and business within that geographic area. Moreover, he finds that HQs organize into geographic area structures are more responsive than those organized into international divisions.

Rugman (2005) makes two comments on the work of Engelhoff (1982). First, the mean foreign sales of the 34 Fortune 500 firms (17 US and 17 European firms) are 50 percent; however, no distinction has been made between intra-regional and inter-regional sales. Second, Egelhoff (1982) assumes that one particular organizational structure always dominates the MNE (functional divisions, international divisions, geographical divisions, and a matrix structure) and can be readily identified based upon statements made by managers through interviews, and the analysis of publicly available information. However, the findings by Rugman and Verbeke (2004) and Rugman (2005, p. 73) shows that "the geographic distribution of foreign sales does matter and that a strong discrepancy between intra-regional and inter-regional sales has important implications for MNE structure. More specifically, the differentiation between backend and customer-end building upon different sets of FSAs should be reflected in the MNE's organizational structure, systems and perhaps even culture".

In a related manner, there is a growing literature on regional components in $\mathrm{MNE}$ organizational and management structures, such as regional headquarters (RHQs) (Heenan, 1979; Grosse, 1981; D’Cruz, 1986; Daniels, 1987; Dunning and Norman, 1987; Morrison et al., 1991; Lassere, 1996; Schuette, 1997; Picard, Boddenwyn and Grosse, 1998; Lehrer and Asakawa, 1999; Yeung et al., 2001; Mori, 2002; Ambos and Shlegelmilch, 2010); regional operating headquarters (Yin and Walsh, 2011); regional offices (Poon and Thompson, 2003; Yeung et al., 2001); regional management centres (Enright, 2005a,b; Piekkari, Nell and Ghauri, 2010), and regional management structures (Mahnke, Ambos and Nell, 2012; Aman, Jaussaud and Schaaper, 2014). These studies emphasize the increasing importance of regions and regional organizational and management structures within MNEs. 
Lasserre (1996) argues that Asian RHQs of Western MNEs serve entrepreneurship enhancing roles (identifying new business opportunities, processing and distributing relevant information on the region, and signaling commitment to regional stakeholders) and integrative roles (exploitation of synergies across national subsidiaries, executing activities in areas where regional resource allocation should occur). However, there is little evidence that any of these roles improve the MNEs' effectiveness in bringing their products to the Asian customers (Rugman, 2005).

Yeung et al. (2001) analyze RHQs in Singapore, building on Lasserre (1996). They define RHQs as business establishments which have control and management responsibilities for the operations of subsidiaries in the same region while regional offices do not have decisionmaking authority on important strategic issues and mainly perform regional operating functions. They argue that the roles depend on three parameters. First, vast geographical distance requires Western MNEs (excepting Japanese and Taiwanese MNEs) to set up RHQs. Second, RHQs enables MNEs to better coordinate their international activities between HQs and Asian subsidiaries and thus the HQs can exercise greater control. Third, RHQs facilitates MNEs to be closer to host country markets and to make faster decisions in response to business opportunities. They find that MNEs establish RHQs in Asia as a part of regional strategy. This implicitly suggests the importance of using RHQs to complement in an idiosyncratic way each MNE's existing FSA bundles (Rugman, 2005).

Picard et al. (1998) examine the 20-year period at the end of the twentieth century of European RHQs, which have been found to gain power and autonomy. Ambos and Schlegelmich (2010) examine the role of regional management of the US and Japanese MNEs in Europe and maintain that a key success factor in a host region is a strategy at regional level, not at the global level. They suggest that RHQs are important in managing global businesses. There are three important advantages of RHQs. First, RHQs play the parental role in organizing and 
coordinating economic activities of foreign subsidiaries within the region, which is the parenting advantage. Second, RHQs translate the global HQs' targets into successful strategies for local markets, which is the knowledge advantage. Third, RHQs may function as a safety valve to handle pressures from global integration and regional adaption to the corporate parent and pressures from regional integration and local adjustment to subsidiaries in the region, which is the organizational advantage.

On the other hand, Piekkari et al. (2010) use a single case study of Kone and find that the parent firm grants varying levels of responsibilities to the regional structures in different periods in the history of RHQ in the Asia-Pacific region. In the 1990s, Kone provides substantial resources to regions. By the late 1990s, Kone emphasizes more global integration and it stripped down the power of the regional structures and downsized regional management. In 2004, Kone reinforces the regional Asia-Pacific office as it has sought to find a balance between the regional and product dimensions in its organizational structures. These scholars find that the persistence of cultural, geographic and language distances, the lack of social integration and strong economic growth in the Asia Pacific region to strengthen the position of the regional organization.

Enright (2005b) examines the role of regional management centres (RMCs). He does not find any significant differences between the roles and the functions of North American and European MNEs assign to their RMCs in the Asia Pacific region. However, there are differences between Western and Japanese MNEs, in which the latter give less prominent roles to their Asia-Pacific regional structures. Japanese RHQs have little autonomy in decisionmaking, because important strategic decisions for the regions are made by the strategic business units (SBUs) in the HQs. The main roles of the Japanese regional structures are to execute the HQs' strategic decisions, to coordinate daily activities, and to support local subsidiaries (Lehrer and Asakawa, 1999; Mori, 2002; Paik and Sohn, 2004). The level of centralization for strategic 
decisions may be attributable to geographic differences, cultural and institutional differences of the home country origins of the parent firms.

Li, Yu and Seetoo (2010) examine the sub-regional HQs of six Taiwanese MNEs in Asia. They identify four geographic decision-making levels: global HQs, RHQs, sub-regional HQs, and local subsidiaries for 22 upstream, downstream, and supporting activities. The R\&D and technology transfer is centralized in the global HQs in Taiwan, whereas regional structures undertake upstream and supporting activities, such as regional supply chain management, production rationalization, regional human resource management, budgeting, and portfolio investments. National subsidiaries are mainly responsible for local sales, marketing, promotion and advertising.

Hoenen, Nell and Ambos (2013) argue that RHQs have entrepreneurial capabilities and responsibilities, beyond the roles of coordination and control of national subsidiaries. RHQs might involve in identifying new local business opportunities, initiating exploitation and setting up new subsidiaries. They find that RHQs' entrepreneurial capabilities increase with external embeddedness and heterogeneous environments.

Aman, Jaussaud and Shaaper (2014) study the regional management structures of French MNEs in the Asia Pacific region. They find that MNEs organize the Asia Pacific region into clusters of countries, where they locate regional management centres (RHQs, regional offices, distribution centres, and local offices) with substantial functions and roles. The main drivers of a regional Asian strategy and organization are that the overall size of the MNE and its sales in Asia; however, the presence of manufacturing activities does not exert any influence. The regional management structures overcome the distance challenge between global HQs and foreign subsidiaries.

\section{CONCLUSIONS}


Multinational enterprises (MNEs) dominate international business and are the key drivers of globalization (Rugman, 2000). Yet, MNEs are regional, not global. The vast majority of MNEs undertake their business activities within their home region of the broad triad of North America, Europe and Asia Pacific. There is no trend towards globalization since the pioneering works by Rugman (2000, 2005), and Rugman and Verbeke (2004). Furthermore, MNEs emphasize the increasingly important roles of regional organizational and management structures which serve as efficient mechanism to coordinate activities between the corporate HQs and foreign subsidiaries in distant host countries. 


\section{REFERENCES}

Aguilera, R.V., Flores, R. \& Vaaler, P.M. (2008). Is it all a matter of grouping? Examining the regional effect in global strategy research, in Tallman, S.B. (Ed.), International Strategic Management: A New Generation (pp 209-228). Northampton: Edward Elgar.

Aharoni, Y. (2006). Book review: The Regional multinationals MNEs and global strategic management. International Business Review, 15(4): 439-446.

Aman, B., Jaussaud, J., and Shaaper, J. (2014). Clusters and regional management structures by Western MNCs in Asia: Overcoming the distance challenge. Management International Review, 54: 879-906.

Ambos, B., and Shlegelmilch, B.B. (2010). The New Role of Regional Management. Basingstoke: Palgrave Macmillan.

Arregle, J-L, Beamish, P.W., \& Hebert, L. (2009). The regional dimension of MNEs' foreign subsidiary localization. Journal of International Business Studies, 40: 86-107.

Arregle, J-L., Miller, T.L., Hitt, M.A., Beamish, P.W. 2013. Do regions matter? An integrated institutional and semi-globalization perspective on the internationalization of MNEs. Strategic Management Journal 34(8), 910-934.

Asmussen, C.G. (2009). Local, regional, or global? Quantifying MNE geographic scope'. Journal of International Business Studies, 40: 1192-1250.

Asmussen, C.G., Pedersen, T., \& Petersen, B. (2007). How do we capture "global specialization" when measuring firms' degree of globalization? Management International Review, 47(6): 1-23

Banalieva, E.R., and Eddleston. K.A. (2011). Home-region focus and performance of family firms: The role of family and non-family leader. Journal of International Business Studies, 42: 1060-1072.

Banalieva, E.R., and Dhanaraj, C. (2013). Home region orientation in international expansion strategies. Journal of International Business Studies, 44: 89-116.

Bartlett, C.A., and Ghoshal, S. (1989). Managing Across Borders: The Transnational Solution. Boston, M.A: Harvard Business School Press.

Bausch, A., Fritz, T., and Boesecke, K. (2007). Performance effects of internationalization strategies: A meta-analysis, in A.M. Rugman (Ed.), Regional Aspects of Multinationality and Performance (pp. 143-176). Amsterdam: Elsevier.

Bell, G., Filatotchev, I. and Rasheed, A. 2012. The liability of foreignness in capital markets: Sources and remedies. Journal of International Business Studies, 43(2): 107-122.

Casson, M. (2016). Alan Rugman's methodology. International Business Review, http://dx.doi.org/10.1016/j.ibusrev.2016.01.015.

Collinson, S., and Rugman, A.M. 2007. The regional focus of Asian multinational enterprises. Asia Pacific Journal of Management, 24(4): 429-446.

Collinson, S., and Rugman, A.M. (2008). The regional nature of Japanese multinational business. Journal of International Business Studies, 39(2): 215-230.

D'Cruz, J. (1986). Strategic management of subsidiaries, in H. Etemad and L.S. Duledue (Eds.) Managing the Multinational Subsidiary (pp. 75-80). London: Croom Helm.

Delios, A., and Beamish, P. W. (2005). Regional and global strategies of Japanese firms. Management International Review, 45(1): 19-36.

Daniels, J. (1987). Bridging national and global marketing strategies through regional operations. International Marketing Review, 4(3): 29-44.

Douglas, S. P., and Wind, Y. (1987). The myth of globalization. Columbia Journal of World Business, Winter: 19-29.

Dunning, J.H., and Norman, G. (1987). The location choices of offices of international companies. Environmental Planning, 19: 613-631. 
Dunning, J.H., Fujita, M., \& Yakova, N. (2007). Some macro-data on the regionalization/ globalization debate: A comment on the Rugman/ Verbeke analysis. Journal of International Business Studies, 38(1): 177-199.

Edwards, T., Jalette, P., and Tregaskis, O. (2012). To what extent is there a regional logic in the management of labour in multinational companies? Evidence from Europe and North America. International Journal of Human Resource Management, 23(12): 2468-2490.

Egelhoff, W.G. (1982). Strategy and structure in multinational corporations: An information processing approach. Administrative Science Quarterly, 27(3): 435-458.

Egelhoff, W.G. (1988a). Strategy and structure in multinational corporations: A revision of the Stopford and Wells model. Strategic Management Journal, 9(1): 1-14.

Egelhoff, W.G. (1988b). Organizing the Multinational Enterprise: An Information-Processing Perspective. Cambridge, M.A: Ballinger.

Egelhoff, W.G. (1991). Information-processing theory and the multinational enterprise. Journal of International Business Studies, 22(3): 341-358.

Elango, B. (2004). Geographic scope of operations by multinational companies: An exploratory study of regional and global strategies. European Management Journal, 22(4): 431-441.

Enright, M.J. (2005a). Regional management centres in the Asia Pacific. Management International Review, 45(1): 59-82.

Enright, M.J. (2005b). The role of regional management centres. Management International Review, 45(1): 83-102.

Filippaios, F., and Rama, R. (2008). Globalisation or regionalisation? The strategies of the world's largest food and beverages MNEs. European Management Journal, 26(1): 59-72

Flores, R., Aguilera, R.V., Mahdian, A. \& Vaaler, P.M. (2013). How well do supra-national regional grouping schemes fit international business research. Journal of International Business Studies, 44: 451-474.

Friedman, T. (2005). The World is Flat: A History of the Twenty-First Century. Farrar, Straus and Giroux.

Ghobadian, A., Rugman, A.M., and Tung, R. L. (2014). Strategies for firm globalization and regionalization. British Journal of Management, 25: 1-5

Gilbert, D.U., and Heinecke, P. (2014). Success factors of regional strategies for multinational corporation: Exploring an appropriate degree of regional management autonomy and regional product/ service adaptation. Management International Review, 54: 615-651.

Govindarajan, V., and Gupta, A. (2001). The Quest for Global Dominance. San Francisco: Josey-Bass/ Wiley.

Grosse, R. (1981). Regional offices of MNCs. Management International Review, 21(1): 4855.

Grosse, R. (2005). Are the largest financial institutions really "global"? Management International Review, 45(1) (Special issue): 129-144.

Heenan, D.A. (1979). The regional headquarters division: A comparative analysis. Academy of Management Journal, 22(2): 410-415.

Heinecke, P. (2011). Success Factors of Regional Strategies for Multinational Corporations. Heidelberg: Springer.

Hoenen, A., Nell, P., and Ambos, B. (2013). MNE entrepreneurial capabilities at intermediate levels: The roles of external embeddedness and heterogeneous environments. Long Range Planning, 47(1-2): 76-86.

IFRS8 Operating Segments. Available at http://eifrs.ifrs.org/eifrs/bnstandards/en/2012/ifrs8.pdf [accessed on September, 26, 2015] IKEA Group, 2010. Welcome Inside, Yearly Summary FY10, IKEA Group. http://www.ikea.com/ms/en_GB/pdf/yearly_summary/ys_welcome_inside_2010.pdf 
Kolk, A. (2010). Social and sustainability dimensions of regionalization and (semi)globalization", Multinational Business Review, 18(1): 51-72.

Lassere, P. (1996). Regional headquarters: The spearhead for Asia Pacific markets. Long Range Planning, 29: 30-37.

Lehrer, M., and Asakawa, K. (1999). Unbundling European operations: Regional management and corporate flexibility in American and Japanese MNCs. Journal of World Business, 34(3): 267-286.

Levitt, T. (1983). The globalization of markets. Harvard Business Review, 61, May-June, 1983. $\mathrm{Li}$, L. (2005). Is regional strategy more effective than global strategy in the US service industries? Management International Review, 45(1): 37-57.

Li, G.H., Yu, C.M., and Seetoo, D.H. (2010). Towards a theory of regional organization: The emerging role of sub-regional headquarters and the impact on subsidiaries. Management International Review, 50(1): 5-33.

Mahnke, V., Ambos, B., Nell, P., and Hobdari, B. 2012. How do regional headquarters influence corporate decisions in networked MNCs? Journal of International Management, 18(3): 293-301.

Mohr, A., Fastoso, F., Wang, C., and Shirodkar (2014). Testing the regional performance of multinational enterprises in the retail sector: the moderating effects of timing, speed and experience. British Journal of Management, 25L S60-S76.

Mori, T. (2002). The role and function of European regional headquarters in Japanese MNCs. Working paper No. 141. Hirosaki University.

Morrison, A.J., Ricks, D.A. \& Roth, K. (1991). Globalization versus regionalization: Which way for the multinational? Organizational Dynamics, 19(3): 17-29.

Mudambi, R. and Puck, J. (2016). A global value chain analysis of the 'regional strategy' perspective. Journal of Management Studies, doi: 10.1111/joms.12189.

Nguyen, Q.T.K. (2014). The regional strategies of British multinational subsidiaries in South East Asia, British Journal of Management, 25: 60-76.

Nguyen, Q.T.K. (2015). The subsidiaries of multinational enterprises operate regionally, not globally. Multinational Business Review, forthcoming.

Nguyen, Q.T.K., and Rugman, A.M. (2015). Multinational subsidiary sales and performance in South East Asia. International Business Review, 24(1): 115-123.

Oh, C.H. (2009). The international scale and scope of European multinationals. European Management Journal, 27(5): 336-343.

Oh, C.H., and Li, J. (2015). Commentary: Alan Rugman and the theory of regional multinationals. Journal of World Business, forthcoming.

Oh, C.H., and Rugman, A.M. (2006). Regional sales of multinationals in the world cosmetics industry. European Management Journal, 24(2-3): 163-173.

Oh, C.H. and Rugman, A.M. (2007). Regional multinationals and the Korean cosmetics industry. Asia Pacific Journal of Management, 24(1): 27-42

Oh, C.H., and Rugman, A.M. (2014) The dynamics of regional and global multinationals, 1999-2008. Multinational Business Review, 22(2): 108-117

Oh, C.H., Sohl, T., and Rugman, A.M. (2015). Regional and product diversification and the performance of retail multinationals. Journal of International Management, 21(3): 220-234

Ohmae, K. 1985. Triad Power: The Coming Shape of Global Competition. New York, N.Y: Free Press.

Osegowitsch, T., \& Sammartino, A. 2008. Reassessing (home-) regionalisation. Journal of International Business Studies, 39(2): 184-196.

Paik, Y., and Sohn, J.H.D. (2004). Striking a balance between global integration and local responsiveness: The case of Toshiba corporation in redefining RHQs' role. Organization Analysis, 12(4): 347-359. 
Picard, J., Boddenwyn, J.J., and Grosse, R. (1998). Centralization and autonomy in international marketing decision making: A longitudinal study. Journal of Global Marketing, 12(2): 5-24.

Piekkari, R., Nell, P., and Ghauri, P.N. 2010. Regional management as a system: A longitudinal case study. Management International Review, 10(4): 513-532.

Poon, J.P.H., and Thompson, E.R. 2003. Developmental and quiescent subsidiaries in the Asia Pacific: Evidence from Hong Kong, Singapore, Shanghai and Sydney. Economic Geography, 79(2): 195-214.

Prahalad, C.K., and Doz, Y.L. (1987). The Multinational Mission: Balancing Global Integration with Local Responsiveness. New York: Free Press.

Qian, G., Khoury, T., Peng, M.W., and Qian, Z. (2010). The performance implications of intraand inter-regional geographic diversification. Strategic Management Journal, 31(9): 10181030.

Qian, G., Li, L., and Rugman, A.M. (2013). Liability of country foreignness and liability of regional foreignness: Their effects on geographic diversification and firm performance. Journal of International Business Studies, 44: 635-647

Ronen, S., and Shenkar, O. (2013). Mapping world cultures: Cluster formation, sources and implications. Journal of International Business Studies, 44: 867-897.

Roth, K., \& Morrison, A.J. (1992). Business-level competitive strategy: A contingency link to internationalization. Journal of Management, 18(3): 473-487.

Rugman, A.M. (2000). The End of Globalization: Why Global Strategy is a Myth \& How to Profit from the Realities of Regional Market'. London: Random House.

Rugman, A.M. (2003a). Regional strategies for service sector multinationals. European Business Journal 15(1): 1-9.

Rugman, A.M. (2003b). Regional strategy and the demise of globalization. Journal of International Management, 9(4): 409-417.

Rugman, A.M. (2005). The Regional Multinationals: MNEs and "Global" Strategic Management. Cambridge: Cambridge University Press.

Rugman, A.M. (2005a). A further comment on the myth of globalization. Journal of International Management, 11(3): 441-445.

Rugman, A.M. (2009). Theoretical aspects of emerging market multinationals, in Ravi Ramamurti and Jitendra V. Singh (Eds.), Emerging Multinationals in Emerging Markets (Cambridge, UK: Cambridge University Press, April 2009), pp. 42-63.

Rugman, A.M. (2014). Subsidiary-specific advantages and multiple embeddedness in multinational enterprises. The MNE Academy Journal, 7: 1-18.

Rugman, A.M., and Brain, C. (2004). Regional strategies of multinational pharmaceutical firms. Management International Review, 44 (Special issue 3): 7-25.

Rugman, A.M., and Collinson, S. (2004). The regional nature of the world's automotive sector. European Management Journal, 22(5): 471-482.

Rugman, A.M., and Collinson, S. (2005). Multinational enterprises in the new Europe: Are they really global? Organizational Dynamics, 34(3): 258-272.

Rugman, A.M., and Collinson, S. (2012). International Business, 6th Edition. Harlow, Essex: Pearson.

Rugman, A.M., and Girod, S. (2003). Retail multinationals and globalization: The evidence is regional. European Management Journal 21(1): 24-37.

Rugman, A.M., and Hodgetts, R. (2001). The end of global strategy. European Management Journal 19(4): 333-343. 
Rugman, A.M, Kudina, A., and Yip, G. (2007). The regional dimension of UK multinationals. IN A.M. Rugman (Ed), Regional Aspects of Multinationality and Performance, Research in Global Strategic Management, Vol. 13, 297-315. Greenwich, CT: JAI Press.

Rugman, A.M., and Li, J. (2007). Will China's multinationals succeed globally or regionally? European Management Journal 25(5): 333-343.

Rugman, A.M., and Nguyen, Q.T.K. 2014. Modern international business theory and emerging economy MNCs, in Alvaro Cuervo-Cazurra and Ravi Ramamurti (eds), Understanding Multinationals from Emerging Markets, Cambridge University Press, pp 53-80.

Rugman, A.M., Nguyen, Q.T.K. \& Wei, Z. 2016. Rethinking the literature on the performance of Chinese multinational enterprises. Management and Organization Review, 12(2): 269-302.

Rugman, A.M., and Oh, C.H. (2008a). The international competitiveness of Asian firms. Journal of Strategy and Management, 1(1): 57-71.

Rugman, A.M., and Oh, C.H. (2008b). Korea's multinationals in a regional world. Journal of World Business, 43(1): 5-15

Rugman, A.M., and Oh, C.H. (2010). Does the regional nature of multinationals affect the multinationality and performance relationship? International Business Review, 19(5): 479-488. Rugman, A.M., and Oh, C.H. (2013). Why the home region matters: Location and regional multinationals. British Journal of Management, 24(4): 463-479.

Rugman, A.M, Oh, C.H., \& Lim, D.S.K. (2012). The regional and global competitiveness of multinational firms. Journal of the Academy of Marketing Science, 40: 218-235.

Rugman, A.M., and Sukpanich, N. (2006). Firm specific advantages, intra-regional sales and performance of multinational enterprises. The International Trade Journal, 20(3): 355-382.

Rugman, A.M., and Sukpanich, N. 2007. Intra-regional sales, product diversity, and the performance of merchandising multinationals. Journal of International Management 13(2): 131-146.

Rugman, A.M., and Verbeke, A. (1992). A note on the transnational solution and the transaction cost theory of multinational strategic management. Journal of International Business Studies, 23(4): 761-772.

Rugman, A.M., and Verbeke. A. (2001). Subsidiary-specific advantages in multinational enterprises. Strategic Management Journal, 22(3): 237-250.

Rugman, A.M., and Verbeke. A. (2004). A perspective on regional and global strategies of multinational enterprises. Journal of International Business Studies, 35(10): 3-18.

Rugman, A.M., and Verbeke. A. (2005). Towards a theory of regional multinationals: A transaction cost economics approach. Management International Review, 45(1): 3-15.

Rugman, A. M., and Verbeke. A. (2007). Liabilities of regional foreignness and the use of firmlevel versus country-level data: A response to Dunning et al. (2007). Journal of International Business Studies, 38(1): 200-205

Rugman, A.M., and Verbeke. A. (2008a). The theory and practice of regional strategy: A response to Osegowitsch and Sammartino. Journal of International Business Studies, 39(2): 326-332.

Rugman, A.M., and Verbeke. A. (2008b). A new perspective on the regional and global strategies of multinational service firms. Management International Review, 4: 397-411.

Rugman, A.M., and Verbeke. A. (2008c). A regional solution to the strategy and structure of multinationals. European Management Journal, 26: 305-313.

Rugman, A.M, Verbeke, A., and Nguyen, Q.T.K. (2011). Fifty years of international business and beyond. Management International Review, 51(6): 755-786.

Seno-Alday, S. (2009). Market characteristics and regionalization patterns. European Management Journal, 27: 366-376.

Schuette, H. (1997). Strategy and organization: Challenges for European MNCs in Asia. European Management Journal, 15(4): 436-445. 
Stevens, M.J., \& Bird, A. (2004). On the myth of believing that globalization is a myth: or the effects of misdirected responses on obsolescing an emergent substantive discourse. Journal of International Management, 10(4): 501-510.

Sukpanich, N., and Rugman, A.M. (2010). Multinationals and the international competitiveness of ASEAN firms, in Philippe Gugler and Julian Chaisse (Eds.) Competitiveness of the ASEAN Countries (pp. 53-81). Elgar.

Venzin, M., Kumar, V., and Kleine, J. (2008). Internationalization of retail banks: A microlevel study of the multinationality-performance relationship. Management International Review, 48(4): 463-485.

Verbeke, A. (2013). International Business Strategy, Second edition Cambridge: Cambridge University Press.

Verbeke, A. and Asmussen, C. G. (2016). Global, local, or regional? The locus of MNE strategies. Journal of Management Studies, DOI: 10.1111/joms.12190.

Verbeke, A. and Kenworthy, T.P. (2008). Multidividional vs. Metanational governance of the multinational enterprise. Journal of International Business Studies, 39(6): 940-956.

Verbeke, A. and Greidanus, N.S. (2009). The end of the opportunism vs trust debate: bounded reliability as a new envelope concept in research on MNE governance. Journal of International Business Studies, 40: 135-152.

Verbeke, A. and Kano, L. (2012). An internalization theory for MNE regional strategy. Multinational Business Review, 20(2): 135-152.

US GAAP $\quad$ FAS 131

http://www.fasb.org/jsp/FASB/Document_C/DocumentPage?cid=1218220124541\&accepted Disclaimer=true [access September 30, 2015]

Westney, D.E. (2006). Review of Alan M. Rugman, The regional multinationals: MNEs and 'global' strategic management. Journal of International Business Studies, 37: 445-449.

Wolf, J., and Egelhoff, W.G. (2002). A reexamination and extension of international strategystructure theory. Strategic Management Journal, 23(2): 181-189.

Wolf, J., Dunemann, T. and Egelhoff, W.G. (2012). Why MNCs tend to concentrate their activities in their home region. Multinational Business Review, 20(1): 67-91.

Yeung, H.W., Poon, J., and Perry, M. (2001). Towards a regional strategy: The role of regional headquarters of foreign firms in Singapore. Urban Studies, 38(1): 157-183.

Yin, E., and Choice, C.J. (2005). The globalization myth: The case of China. Management International Review, 45(1): 103-120.

Yin, M.S., and Walsh, J. (2011). Analyzing the factors contributing to the establishment of Thailand as a hub for regional operating headquarters. Journal of Economics and Behavioral Studies, 2(6): 275-287.

Yip, G.S. 1992. Total Global Strategy: Managing for Worldwide Competitive Advantage.

Englewood Cliffs, NJ: Prentice Hall.

Zaheer, S. 2002. The liability of foreignness, redux: A commentary. Journal of International Management, 8: 351-358. 